\title{
Can pre-hospital administration reduce time to initial antibiotic therapy in septic patients?
}

Daniel Cudini, Karen Smith, Stephen Bernard, Michael Stephenson, Emily Andrew, Peter Cameron, Mark Lum, Andrew Udy, on behalf of the ARISE Investigators.

Corresponding author: Mr Daniel Cudini, BEx Sci, BEmergHIth (Paramedic), Grad Dip EmergHIth (ICP), MPA, RP, Intensive Care Paramedic, Ambulance Victoria;

\section{daniel.cudini@ambulance.vic.gov.au}

Professor Karen Smith, BSc (Hons), Grad Cert Exec BA, Grad Dip Epi and Biostats, PhD, Director Centre for Research and Evaluation, Ambulance Victoria;

Professor Stephen Bernard, MBBS, MD, FACEM, FCICM, FCCM, Medical Director, Ambulance Victoria;

Associate Professor Michael Stephenson, B Hlth Sci, Grad Dip HIth Sci (MICA), RN, Executive Director, Ambulance Victoria;

Emily Andrew, BSc(Biomedical) MBiostat, PhD Candidate, Research Governance Manager, Ambulance Victoria;

Professor Peter Cameron, MBBS, MD, FACEM, Academic Director, The Alfred Emergency and Trauma Centre;

Mr Mark Lum, Medical Student, The Alfred Hospital;

This is the author manuscript accepted for publication and has undergone full peer review but has not been through the copyediting, typesetting, pagination and proofreading process, which may lead to differences between this version and the Version of Record. Please cite this article as doi: $10.1111 / 1742-6723.13282$

This article is protected by copyright. All rights reserved. 
Professor Andrew A Udy, BHB, MBChB, FCICM, PhD, Deputy Director ANZIC-RC, Monash University;

On behalf of the ARISE Investigators.

\section{ACKNOWLEDGEMENTS}

The ARISE study was a collaboration of the Australian and New Zealand Intensive Care Society Clinical Trials Group (ANZICS CTG), The Australasian College for Emergency Medicine and the Australian and New Zealand Intensive Care Research Centre (ANZIC-RC), Monash University. The trial was endorsed by the Irish Critical care Trials Group and the College of Intensive Care Medicine. The ARISE Management and Steering Committee: S. Peake (Chair), A. Delaney, R. Bellomo, P. A. Cameron, D. J. Cooper, A. Cross, C. Gomersall, C. Graham, A .M. Higgins, A. Holdgate, B.D. Howe, I. Jacobs, S. Johanson, P. Jones, P. Kruger, C. McArthur, J. Myburgh, A. Nichol, V. Pettilä, D. Rajbhandari, S.A.R. Webb, A. Williams, J. Williams, P. Williams.

The ARISE site investigators in Victoria, Australia: The Alfred Hospital, Melbourne - V. Bennett, J. Board, P. McCracken, S. McGloughlin, V. Nanjayya, A. Teo. Austin Health, Melbourne - R. Bellomo, S. Bolch, G. Eastwood, F. Kerr, L. Peak, H. Young. Bendigo Hospital, Bendigo - J. Edington, J. Fletcher, J. Smith. Box Hill Hospital, Melbourne - A. Cross, D. Flemming, M. Grummisch, A. Purdue. Central Gippsland Health Service, Sale - T. Coles, H. Connor, J. Dennett, A. Van Berkel. Dandenong Hospital, Melbourne - G. Braitberg, B.O’Bree, K. Shepherd, S. Vij. Frankston Hospital, Melbourne - 
S. Allsop, D. Haji, K. Haji, J. Vuat. Geelong Hospital, Geelong - A. Bone, T. Elderkin, N. Orford, M. Ragg. Monash Medical Centre, Clayton - J. Dowling, P. Galt, T. Lamac, D. Lightfoot, C. Walker. Royal Melbourne Hospital, Melbourne - C. Maclsaac, K. Gorman, A. Jordan, L. Moore. St. Vincent's Hospital, Melbourne - E. Farone, J. Holmes, J. Santamaria, C. Winter. Western Hospital, Footscray - S. Bates, J. Butler, C. French, A. Tippett. 


\section{ABSTRACT}

Objective: To quantify the potential time saved with pre-hospital antibiotic therapy in sepsis.

Methods: Study data for adult patients transported by Ambulance Victoria (AV), and enrolled into the Australasian Resuscitation In Sepsis Evaluation (ARISE), were linked with pre-hospital electronic records.

Results: An AV record was identified for 240 of 341 ARISE patients. The pre-hospital case notes referred to potential infection in 165 patients. The median time to first antibiotic administration from loading the patient into the ambulance was 107 [74-160] minutes.

Conclusions: ARISE patients in Victoria were frequently identified pre-hospital. An opportunity exists to study the feasibility of pre-hospital antibiotic therapy. 


\section{INTRODUCTION}

With an annual incidence in adults of up to 300 cases per 100,000 population ${ }^{1}$, and in-hospital mortality as high as $50 \%{ }^{2}$, sepsis is a global health priority. Current management primarily focuses on early recognition and administration of broad-spectrum antibiotic therapy. Paramedics potentially play a key role in this, although there is a paucity of literature describing the prehospital features of sepsis, and whether targeted interventions in this setting will improve processes of care.

The aims of this study were to describe the pre-hospital characteristics of Victorian patients enrolled in the Australasian Resuscitation In Sepsis Evaluation (ARISE) ${ }^{3}$, and to quantify the potential time saved if antibiotics were administered at scene.

This article is protected by copyright. All rights reserved. 


\section{METHODOLOGY}

ARISE was conducted in 51 centres across Australia and New Zealand, enrolling patients presenting to the emergency department (ED) with severe sepsis or septic shock ${ }^{3}$. Patients were eligible to be enrolled in ARISE if they presented with suspected or confirmed infection, had two or more of the systemic inflammatory response syndrome criteria, and evidence of refractory hypotension (SBP $<90 \mathrm{mmHg}$ or MAP $<65 \mathrm{mmHg}$ despite $1 \mathrm{~L}$ IV fluid) or hypoperfusion (blood lactate $\geq 4.0 \mathrm{mmol} / \mathrm{L}$ ) within 6 hours of presentation ${ }^{4}$. All enrolled patients over 18 years of age and transported by Ambulance Victoria (AV) to a participating ED, were included in this sub-study.

AV electronic patient care records were extracted, and linked with ARISE study data via secure data exchange. Only de-identified data were included, with the final dataset comprising demographic, pre-hospital, illness severity, diagnostic, and outcome variables. The study received low risk ethics approval from The Alfred Hospital (30/17) and Monash University (11437) Human Research Ethics Committees, and AV Research Governance Committee (R17-013), with a waiver of individual participant consent.

Continuous data are presented as the median (interquartile range [IQR]). Categorical data are presented as counts (\%). No imputation was made for missing data, and all proportions were adjusted accordingly. All analyses were undertaken using IBM SPSS Statistics Version 25 (Chicago, $\mathrm{IL})$. 


\section{RESULTS}

341 patients were enrolled into ARISE in Victoria. Following linkage, 240 (70.4\%) were identified as being transported by AV. Demographic, pre-hospital, illness severity, diagnostic, and outcome data are provided in Table 1 . The paramedic case notes referred to potential infection in 165 patients (68.7\%). Overall, $62.9 \%$ (144 of 229 patients) were febrile (max temperature $>38^{\circ} \mathrm{C}$ ), 56.1\% (134 of 239 patients) were tachypnoeic ( $\max R R>22$ ), 71.3\% (169 of 237 patients) were tachycardic (max HR > 100), 61.6\% (146 of 237 patients) were hypotensive (min SBP $<100 \mathrm{mmHg}$ ), and $36.8 \%$ (88 of 239 patients) were confused (min GCS $<15$ ) pre-hospital. The quick sepsisrelated organ failure assessment (qSOFA) score was positive in 58.2\% (138 of 237 patients). 36.8\% (88 of 239 patients) received IV fluid pre-hospital (median 1 [0.5-1.4] L).

The median [IQR] pre-hospital contact time (arrival at scene through to off-stretcher at hospital) was 67 [51-83] minutes. The median [IQR] ambulance transport time was 29 [20-42] minutes and time to first antibiotic administration from loading the patient into the ambulance was 107 [74160] minutes. All cause 90 -day mortality was $17.5 \%$ (42 of 240 patients).

INSERT TABLE 1.

This article is protected by copyright. All rights reserved. 


\section{DISCUSSION}

This work reinforces a number of important observations concerning pre-hospital management of severe sepsis. Of note, a significant proportion of ARISE patients were transported by AV, a finding consistent with previous literature ${ }^{5}$, and which reinforces the role of pre-hospital practitioners in delivering optimal care to this group. Moreover, demonstrable physiological abnormalities were recorded in many cases, representing objective indicators of potential severe infection that are routinely assessed pre-hospital. Finally, these data suggest a potential window of opportunity to administer antibiotic therapy at the scene, although whether feasible or indeed appropriate, remains uncertain.

The strength of this analysis relates to the utilisation of the ARISE dataset, a high-quality, multicentre randomised controlled trial. All patients were enrolled on the basis of pre-specified criteria, thereby ensuring a consistent diagnosis, using the most widely accepted definition of severe sepsis / septic shock at the time. However, while this allows for greater homogeneity, we are not able to further interrogate the utility of any particular pre-hospital feature in ruling sepsis in or out. Similarly, further analysis is limited by the relatively small sample size, and use of data from a select region only. Finally, some data were missing (at random), due to the retrospective nature of the analysis.

This article is protected by copyright. All rights reserved. 


\section{CONCLUSION}

ARISE patients in Victoria were frequently identified by paramedics prior to arriving in the ED, and manifest abnormal vital signs pre-hospital. An opportunity exists to further study the feasibility of pre-hospital antibiotic therapy in septic patients. 


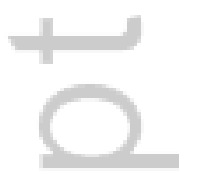

This article is protected by copyright. All rights reserved. 


\section{REFERENCES}

1. Jawad I, Luksic I, Rafnsson SB. Assessing available information on the burden of sepsis: global estimates of incidence, prevalence and mortality. J Glob Health 2012; 2(1):010404.

2. Reinhart K, Daniels R, Kissoon N, Machado FR, Schachter RD, Finfer S. Recognizing sepsis as a global health priority-A WHO resolution. N Engl J Med 2017; 377(5):414-417.

3. ARISE Investigators; ANZICS Clinical Trials Group, Peake SL, Delaney A, Bailey M, Bellomo R, Cameron PA, Cooper DJ, Higgins AM, Holdgate A, Howe BD, Webb SA, Williams P. Goaldirected resuscitation for patients with early septic shock. N Engl J Med 2014; 371(16):1496-506.

4. Delaney AP, Peake SL, Bellomo R, Cameron P, Holdgate A, Howe B, Higgins A, Presneill J, Webb S, ARISE Investigators. The Australasian Resuscitation in Sepsis Evaluation (ARISE) trial statistical analysis plan. Crit Care Resusc 2013; 15(3):162-171.

5. Studnek JR, Artho MR, Garner CL, Jr., Jones AE. The impact of emergency medical services on the ED care of severe sepsis. Am J Emerg Med 2012; 30(1):51-56. 
Table 1 - Descriptive Variables

\begin{tabular}{|c|c|}
\hline Variable & $\mathrm{n}=\mathbf{2 4 0}$ \\
\hline Age, years, median [IQR] & $67[52-76]$ \\
\hline Male gender, $\mathrm{n}(\%)$ & $137(57.1)$ \\
\hline Charlson Comorbidity Index, median [IQR] & $1[0-2]$ \\
\hline Dispatch time, minutes, median [IQR] & $13[10-22]$ \\
\hline Scene time, minutes, median [IQR] $(n=236)$ & 20 [14-28] \\
\hline Transport time, minutes, median [IQR] $(n=236)$ & 29 [20-42] \\
\hline Off-stretcher*, minutes, median [IQR] $(n=236)$ & $11[7-19]$ \\
\hline $\begin{array}{l}\text { Initial Primary Paramedic Assessment, n (\%) } \\
\text { - Infection related } \\
\text { - } \quad \text { Non-infection related }\end{array}$ & $165(68.7)$ \\
\hline $\begin{array}{l}\text { Temperature, }{ }^{\circ} \mathrm{C} \text {, median }[\mathrm{IQR}](\mathrm{n}=229) \\
\text { - } \text { Initial } \\
\text { - } \quad \text { Maximum } \\
\text { - Minimum }\end{array}$ & $\begin{array}{l}38.7[37.6-39.5] \\
38.7[37.7-39.5] \\
38.6[37.6-39.4]\end{array}$ \\
\hline $\begin{array}{l}\mathrm{SpO}_{2}, \%, \text { median }[\mathrm{IQR}](\mathrm{n}=143) \\
-\quad \text { Initial } \\
-\quad \text { Maximum } \\
-\quad \text { Minimum }\end{array}$ & $\begin{array}{l}90[87-95] \\
96[94-99] \\
90[86-95]\end{array}$ \\
\hline $\begin{array}{l}\text { GCS*, median }[\text { IQR }](n=239) \\
-\quad \text { Initial } \\
\text { - Maximum }\end{array}$ & $\begin{array}{l}15 \text { [14-15] } \\
15 \text { [15-15] }\end{array}$ \\
\hline
\end{tabular}

This article is protected by copyright. All rights reserved. 


\begin{tabular}{|c|c|}
\hline - Minimum & 15 [14-15] \\
\hline Proportion GCS < 15, n (\%) (n=239) & $88(36.8)$ \\
\hline \multicolumn{2}{|l|}{$\mathrm{RR}^{*}, /$ min, median $[\mathrm{IQR}](\mathrm{n}=239)$} \\
\hline - Initial & $24[18-36]$ \\
\hline - Maximum & $24[18-36]$ \\
\hline - Minimum & $20[18-28]$ \\
\hline \multicolumn{2}{|l|}{ Heart Rate, / min, median [IQR] $(n=237)$} \\
\hline - Initial & $113[99-130]$ \\
\hline - Maximum & $113[99-130]$ \\
\hline - Minimum & $108[92-120]$ \\
\hline \multicolumn{2}{|l|}{ Systolic BP, mmHg, median [IQR] ( $\mathrm{n}=237)$} \\
\hline - Initial & $90[80-120]$ \\
\hline - Maximum & $110[90-130]$ \\
\hline - Minimum & $90[75-110]$ \\
\hline Any Pre-hospital IV fluid, n (\%) $(n=239)$ & $88(36.8)$ \\
\hline Volume Pre-hospital IV fluid, ml, median [IQR] $(n=88)$ & $1000[500-1425]$ \\
\hline Screening* Lactate, $\mathrm{mmol} / \mathrm{L}$, median [IQR] $(\mathrm{n}=89)$ & $5.8[4.6-7.5]$ \\
\hline Screening* MAP, mmHg, median [IQR] $(n=111)$ & $58[52-62]$ \\
\hline Screening* SBP, mmHg, median [IQR] $(n=161)$ & $80[75-85]$ \\
\hline \multicolumn{2}{|l|}{ Source of Sepsis, n (\%) (n=239) } \\
\hline - Abdomen & $10(4.2)$ \\
\hline - Blood & $21(8.8)$ \\
\hline - Central nervous system & $5(2.1)$ \\
\hline
\end{tabular}

This article is protected by copyright. All rights reserved. 


\begin{tabular}{|c|c|}
\hline - Lungs & 95 (39.6) \\
\hline - Medical: Other & $19(7.9)$ \\
\hline - Medical: Soft tissue & $16(6.7)$ \\
\hline - $\quad$ Not identified & $17(7.1)$ \\
\hline - Surgical: Other & $3(1.3)$ \\
\hline - Surgical: Soft tissue & $5(2.1)$ \\
\hline - Urinary tract & $48(20.0)$ \\
\hline \multicolumn{2}{|c|}{ Time to antibiotics, minutes, median [IQR] $(n=236)$} \\
\hline - From dispatch & 152 [113-204] \\
\hline - $\quad$ From arrival at patient & $134[97-182]$ \\
\hline - From patient loaded & $107[74-160]$ \\
\hline - $\quad$ From triage at ED & 75 [41-126] \\
\hline Alive at ED discharge, $\mathrm{n}(\%)$ & $237(98.8)$ \\
\hline 28-day mortality, n (\%) & $32(13.3)$ \\
\hline 90-day mortality, n (\%) & $42(17.5)$ \\
\hline
\end{tabular}

inclusion/exclusion into ARISE. * Off-stretcher refers to the documented time AV patient handover occurred with ED staff and in hospital care commenced. * GCS refers to the Glasgow Coma Score. * RR refers to Respiratory Rate. *BP refers to Blood Pressure. 


\section{University Library}

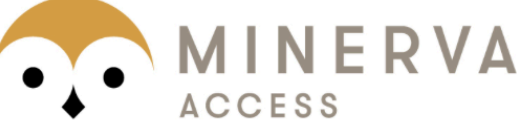

A gateway to Melbourne's research publications

Minerva Access is the Institutional Repository of The University of Melbourne

\section{Author/s:}

Cudini, D;Smith, K;Bernard, S;Stephenson, M;Andrew, E;Cameron, P;Lum, M;Udy, A;Peake, S;Delaney, A;Bellomo, R;Cameron, PA;Cooper, DJ;Cross, A;Gomersall, C;Graham,

C;Higgins, AM;Holdgate, A;Howe, BD;Jacobs, I;Johanson, S;Jones, P;Kruger, P;McArthur, C;Myburgh, J;Nichol, A;Pettila, V;Rajbhandari, D;Webb, SAR;Williams, A;Williams,

J;Williams, $\mathrm{P}$

Title:

Can pre-hospital administration reduce time to initial antibiotic therapy in septic patients?

Date:

2019-08-01

\section{Citation:}

Cudini, D., Smith, K., Bernard, S., Stephenson, M., Andrew, E., Cameron, P., Lum, M., Udy, A., Peake, S., Delaney, A., Bellomo, R., Cameron, P. A., Cooper, D. J., Cross, A., Gomersall, C., Graham, C., Higgins, A. M., Holdgate, A., Howe, B. D. ,... Williams, P. (2019). Can pre-hospital administration reduce time to initial antibiotic therapy in septic patients?. EMERGENCY MEDICINE AUSTRALASIA, 31 (4), pp.669-672. https:// doi.org/10.1111/1742-6723.13282.

Persistent Link:

http://hdl.handle.net/11343/285657 